\title{
Effects of habitat fragmentation on the fitness of two common wetland species, Carex davalliana and Succisa pratensis
}

\begin{abstract}
Small habitat size and spatial isolation may cause plant populations to suffer from genetic drift and inbreeding, leading to a reduced fitness of individual plants. We examined the germination, establishment, growth, and reproductive capacity of two characteristic species of mown fen meadows, Carex davalliana, and Succisa pratensis, common in Switzerland. Plants were grown from seeds, which were collected in 18 habitat islands, differing in size and in degree of isolation. We used both common garden and reciprocal transplant experiments to assess effects of habitat fragmentation. In the common garden, plants of Carex originating from small habitat islands yielded $35 \%$ less biomass, $30 \%$ fewer tillers, and $45 \%$ fewer flowering tillers than plants from larger ones. In contrast, plants of Succisa originating from small habitat islands yielded $19 \%$ more biomass, $14 \%$ more flower heads and $35 \%$ more flowers per flower head than plants from larger ones. Moreover, plants of Succisa from small isolated habitats yielded $32 \%$ more rosettes than did plants from small connected islands. Reciprocally transplanted plants of Succisa originating from small habitat islands produced $7 \%$ more rosettes than plants from larger ones. There was no effect of small habitat size and isolation on germination and establishment of both species in the field. Our results document genetic differences in performance attributable to habitat fragmentation in both species. We suggest that fitness loss in Carex is caused by inbreeding depression, whereas in Succisa the differences in fitness are more likely caused by genetic differentiation. Our study implies that habitat fragmentation affects common habitat-specific species, such as Carex and Succisa, as well as rare ones.
\end{abstract}

D.A.P. Hooftman $(\bowtie) \cdot$ M. van Kleunen $\cdot$ M. Diemer Institut für Umweltwissenschaften, Universität Zürich, Winterthurerstrasse 190, 8057 Zürich, Switzerland

Present address:

D.A.P. Hooftman, Institute for Biodiversity and Ecosystem Dynamics, P.O. Box 94062, 1090 GB Amsterdam, The Netherlands, e-mail: hooftman@science.uva.nl, Fax: +31-20-5257832
Keywords Calcareous fen meadows - Establishment . Genetic differences $\cdot$ Habitat size $\cdot$ Reproduction

\section{Introduction}

As a consequence of human activities, many habitats of plant populations have become small, fragmented, and isolated. This habitat fragmentation has concomitantly resulted in declining population sizes, which can impair species persistence (Saunders et al. 1991; Eriksson 1996), even when appropriate management is maintained and habitat quality remains intact (Fischer and Stöcklin 1997; Stöcklin and Fischer 1999; Lienert et al. 2002a). Smaller populations in such smaller habitat islands are more vulnerable to demographic and environmental stochasticity, and therefore face a higher risk of extinction (Boyce 1992; Schemske et al. 1994). Moreover, in small populations genetic drift may increase and result in a lower genetic variability (Barrett and Kohn 1991; Young et al. 1996; Berge et al. 1998), and as a consequence the level of inbreeding may increase (van Treuren et al. 1991; Ellstrand and Elam 1993). This may adversely affect individual plant fitness components through inbreeding depression and consequently lifetime fitness and so decrease the population viability (Menges 1990; Ellstrand and Elam 1993; Oostermeijer et al. 1995; Young et al. 1996).

The fitness of plants in the remaining small habitat islands may further be reduced because biotic interactions are disrupted. Small habitat islands are less attractive for pollinating insects, which may result in pollen limitation and lower seed set (Agren 1996; Kwak et al. 1998). On the other hand, individual plants with flowers that are more attractive and with higher investment in clonal growth will have an advantage in this situation. In this instance, habitat fragmentation could lead to a specific selection for these traits.

The effects of small habitat size on fitness could be less severe when gene flow between the remaining habitat islands is not precluded by isolation (Berge et al. 1998; 
Richards 2000), because gene flow between populations, either by seeds or pollen, has a homogenizing effect and will prevent a decrease in genetic variability (Harrison and Hastings 1996).

Few studies have separated the effects of small habitat size and isolation in natural populations, e.g. Ouborg (1993), Lienert et al. (2002b). Moreover, none of them used a spatially controlled field design, based on explicit distance and size criteria (Hooftman et al. 1999; but see Lienert et al. 2002b). Moreover, most studies focussed on rare species in fragmented habitats, although certainly common habitat-specific species may be affected by habitat fragmentation as well. Common habitat-specific species are likely to have important ecosystem functions, because they form the matrix of the community (Power et al. 1996).

In a previous study within the same experimental setup as the current study (D. A. P. Hooftman and M. Diemer, submitted), we found that the demographic structure of populations of the forb Succisa pratensis and the sedge Carex davalliana was adversely affected by habitat size and by geographical isolation, respectively. The observed changes in the demographic structure of populations in small and isolated habitat islands may either reflect environmental differences between habitat islands or differences in management regimes (c.f. Oostermeijer et al. 1994; Heglund et al. 2001), or genetic differences as a consequence of genetic drift or local adaptation. To distinguish between phenotypic and genotypic effects on individual plant fitness of both species, we performed a common garden experiment and reciprocal transplant experiments of seeds and seedlings from populations subject to differing levels of habitat fragmentation. Environmental (phenotypic) effects should be reflected in differences in the germination of seeds and in survival and growth of seedlings planted in the different habitat island types (Antonovics and Primack 1982; Schmid 1992; Galloway and Fenster 2000). Differences in performance of plants from different habitat islands of origin, when grown under common environmental conditions, on the other hand, most likely reflect genetic differences (Fischer et al. 2000), although also maternal environmental effects through seed quality may contribute to them (Westoby et al. 1996). If alterations in performance are a consequence of genetic drift, plants of small and isolated habitat islands are expected to perform worse in a common environment (Helenurm 1998; Fischer et al. 2000). In contrast, local adaptation should result in a better performance of "home" plants than of "away" plants, when they are reciprocally transplanted between the different habitat island types (Schmid 1985; van Tienderen and van der Toorn 1991; Nagy and Rice 1997), which cannot be tested in a common garden experiment.

We addressed the following questions:

1. Is growth and reproduction of plants in a common garden affected by the size and degree of isolation of the habitat of origin?
2. Is the germination and establishment rate in the field affected by the habitat of origin, or by the size and degree of isolation of the local habitat?

3. Are survival, growth and reproduction of plants in the field affected by the size and degree of isolation of the local habitat, or by the size and degree of isolation of the habitat of origin?

4. If genetic differences occur among plants originating from different habitat island types, can these differences be attributed to genetic drift or to local adaptation?

\section{Materials and methods}

Study species and habitat description

Carex davalliana, SM. and Succisa pratensis, Moench. (nomenclature according to Binz and Heitz 1990) are common in Switzerland (Lauber and Wagner 1998) and are characteristic indicator species of wet calcareous fen meadows of the Caricion davallianae alliance (Görs 1977; Hooftman et al. 1999). These fen meadows occur on the slopes of mountains in small depressions with a high groundwater level or slopes with aquifer discharges. The soils of these fen meadows are fully hydrated throughout the majority of the growing season. Their vegetation is dominated by graminoids, mostly sedges, and harbours many forb species. Calcareous fen meadows belong to the most species-rich wetland communities in Europe (Ellenberg 1996), with nearly 50\% of all threatened species of Switzerland occurring in wetlands (Landolt 1991). Nowadays, as a consequence of changed land-use, these fen meadows are highly fragmented in north-eastern Switzerland.

Carex davalliana (Cyperaceae) is the most common graminoid species in these fen meadows. This dioecious, clonal plant flowers May-June, and is wind-pollinated. It forms loose tussocks, and has a high tiller turnover, i.e. tillers live for $2-3$ years only.

Succisa pratensis (Dipsacaceae) is the most common forb species in these fen meadows. This hermaphroditic, perennial species flowers July-August, and is insect pollinated. It is selfcompatible, but selfing is rare in the field. In addition, clonal growth has been described in Succisa (Adams 1955), and the longevity of genets is high (>25 years). Furthermore, Succisa is a keystone species for phytophagous insects in Swiss fen meadows (Peintinger 1999).

\section{Habitat islands}

In this study, we used 18 pre-alpine fen meadows, which were arranged in six clusters (fen systems), within two different regions in north-eastern Switzerland. Individual fen systems will be referred to by the following localities: Alpthal, Sattel, Nesslau, Ebnat-Kappel, Grabserberg, and Wildhaus. A detailed list of the composition, locations, size of the fen meadows in these fen systems, and details on the experimental design and the rationale behind these fen systems is given in Hooftman et al. (1999). Briefly, each fen system consisted of a large habitat island of $>5$ ha (main island) and two small habitat islands of ca. 0.5 ha. The two small islands differ in the geographical distance from the main island (near island: ca. $50 \mathrm{~m}$, distant island: ca. 1,000 m). The two distance classes were chosen on the basis of published data: gene flow becomes extremely rare beyond distances of approximately $1,000 \mathrm{~m}$ (Levin 1988), but may already be reduced at distances of several tens of metres (e.g. Primack and Miao 1992; Morris 1994). The near island is therefore assumed to have a reduced but sporadic gene flow from the main island, whereas the distant island is assumed to be genetically isolated. This spatially controlled field design allowed us to distinguish between the effect of small habitat 
size and the effect of isolation (Hooftman et al. 1999). To preclude differences between fen meadows caused by differences in altitude and management, we only chose montane fen meadows in the altitude range of 900-1,400 $\mathrm{m}$ a.s.1., which are mown once annually in early September, hence management effects on plant performance can be ruled out (c.f. Oostermeijer et al. 1994; Heglund et al. 2001).

\section{Seed collection}

In each habitat island, we made a bulk collection of seeds from more than 25 randomly chosen individuals of Carex in July 1998 , and of Succisa in August 1998 and 1999. To avoid possible edge effects on seed quality, we did not collect seeds within a distance of $2 \mathrm{~m}$ from the edge of each habitat. Since seed mass affects subsequent growth (Westoby et al. 1996), we tested for systematic differences among habitat islands. The average seed mass, expressed as a mean of five samples of 100 randomly chosen seeds per habitat island, did not significantly differ among the three habitat island types for both species (Carex, $F_{1,6}=1.3, P>0.3$; Succisa, $F_{1.9}=0.14, P>0.8$ )

\section{Common garden experiments}

To study whether there were genetic differences in growth and reproduction between plants originating from the main, near and distant island types, we performed a common garden experiment. In January 1999, we sowed seeds in Petri dishes filled with vermiculite in a climate chamber with a day/night regime of 14/ $10 \mathrm{~h}$ and a temperature regime of $20 / 10^{\circ} \mathrm{C}$. Emerged seedlings were planted in a 1:1 mixture of sand and soil, and kept in a greenhouse before planting them in the garden of the Institut für Umweltwissenschaften in Zürich (Switzerland) in May 1999. We mixed the loamy soil of the garden with sand to create low nutrient conditions comparable to those in fen meadows. We excessively watered the soil to create a wet environment and to avoid drought stress.

We planted six to ten seedlings of Carex originating from each habitat island in the garden (with the exception of the distant island in Alpthal and the near island in Wildhaus, which yielded one and no seedlings, respectively). The plants (i.e. 84 single tiller genets) were randomly planted at a $15-\mathrm{cm}$ spacing. Fourteen months after the start of the experiment (July 2000), we counted the number of vegetative and flowering tillers of each plant (all had survived), and determined aboveground biomass after drying to constant mass at $70^{\circ} \mathrm{C}$.

We planted six to ten seedlings of Succisa originating from each habitat island in the garden (with the exception of the near island in Wildhaus and the distant island in Nesslau, which had three and no seedlings, respectively). The plants (i.e. 148 genets in the four to six leaf phase) were randomly planted at a $10-\mathrm{cm}$ spacing. Fifteen months after the start of the experiment (August 2000), we counted the number of rosettes (eight plants had died), the number of flower heads per plant and the number of flowers of the first two flower heads to ripen on each genet. Subsequently, we determined aboveground biomass after drying to constant mass at $70^{\circ} \mathrm{C}$.

\section{Reciprocal transplant experiments}

Seeds

To study effects of the size and isolation of habitat islands on germination and establishment, and to study whether seeds originating from different habitat types are locally adapted, we reciprocally transplanted seeds of Carex and Succisa among main near and distant islands within each of five fen systems (we could not collect enough seeds in Nesslau to conduct the reciprocal transplant experiments). Inseeding was done in late September 1998, shortly before the snow covered the fen meadows. For each species, we randomly selected four plots within each habitat island.
The plots were subdivided into four subplots of $20 \times 20 \mathrm{~cm}$ with a buffer zone of $5 \mathrm{~cm}$ between them. In each of three subplots within each plot, we sowed 50 seeds originating from one of the three island types of the respective fen system. Because it was impossible to tag individual seeds, we used the fourth subplot as a control to estimate natural germination rates. The total number of subplots used in this study was 240 , of which ca. 16 had to be excluded at the end of the experiment because tags of the plots were lost. This experiment was repeated for Succisa with 100 instead of 50 seeds per subplot in September 1999. We recorded the number of seedlings of Carex and Succisa in each subplot, to measure the germination rates, in June and July 1999, respectively. One year later (June and July 2000), we recorded the number of adult tillers (Carex) and the number of established juvenile plants (Succisa) in each subplot to measure the establishment rates. In July 2000, we counted the number of seedlings within each subplot of the second germination experiment (1999) of Succisa.

\section{Seedling establishment of Succisa}

To study effects of the local habitat island type on survival, growth and reproduction of Succisa, and to study whether plants originating from different habitat islands were locally adapted, we reciprocally transplanted seedlings (i.e. genets in the four to six leaf phase) of Succisa among main, near and distant islands within each of five fen systems in May 1999

Pre-cultivation of seedlings was identical to the one described for seedlings used in the common garden experiment. Within each habitat island, we randomly selected four plots of $1 \mathrm{~m}^{2}$. Within each plot, we planted and marked two seedlings from each of the three habitat island types comprising a given system (totalling 360 seedlings). In Wildhaus, 43 instead of 72 seedlings were transplanted because of a lack of seedlings. Fifteen months after the start of the experiment (August 2000), we recorded whether the plants had survived, and on the surviving plants we measured the same traits as in the common garden experiment.

\section{Statistical analyses}

We analysed all quantitative variables with a hierarchical analysis of variance with sequential sum of squares (procedure GLM in the statistical package SPSS; SPSS, Chicago, Ill.). The model used for the analyses of the data of the common garden experiment was presented in Hooftman et al. (1999). Briefly, "regions" and "fen systems", which are nested within "regions", were treated as block effects, and "island types" as a fixed effect. By using a hierarchical design, we are able to account for the variation explained by regional differences and among fen systems in advance to testing the effects of habitat fragmentation, which is of primary interest here. To distinguish between the effect of small habitat size and of isolation, we specified two linear contrasts: the effect of habitat size was tested with a contrast between the main island and both small islands, subsequently the effect of isolation was tested with a contrast between the near and the distant small island. To correct the effects of habitat fragmentation for variation among fen systems, we quantified means of each habitat island type by using an estimated marginal (predicted) means procedure. All quantitative variables were log-transformed prior to analysis to ensure normality and homoscedasticity. For analysing the data of the reciprocal transplant experiments, we used an extension of the model presented above (Table 1). To distinguish between effects of the island type of origin (source island) and effects of the local island type in which plants were planted (target island), we included both effects and their interaction in the model. Because of the overall low explanatory power of the variation by this interaction, no additional linear contrasts were included. In the seed transplantation experiment, we first tested whether the number of seedlings in the experimentally sown subplots was higher than in the matching control subplots. To test whether the binary data of seedling survival in the reciprocal transplant experiment differed 
Table 1 Skeleton model of a nested hierarchical ANOVA (GLM procedure), using sequential sum of squares, for testing the effects of habitat fragmentation in reciprocal transplant experiments. $p z$ covariable, $r$ Region, $f$ fen system, $h$ habitat size effect, $s$ source island, $t$ target island, $i$ isolation effect, res residuals

\begin{tabular}{|c|c|c|c|}
\hline Source of variation & $d f$ & Mean squares & $F$ \\
\hline Covariable & 1 & $\mathrm{Mpz}$ & $\mathrm{Mpz} / \mathrm{Mfs}$ \\
\hline Region & 1 & $\mathrm{Mr}$ & $\mathrm{Mr} / \mathrm{Mf}$ \\
\hline Fen system (nested within region) & 3 & Mf & Mf/Mres \\
\hline Habitat size effect (source island) & 1 & Mhs & Mhs/Mfs \\
\hline Habitat size effect (target island) & 1 & Mht & $\mathrm{Mht} / \mathrm{Mft}$ \\
\hline Isolation effect (source island) & 1 & Mis & Mis/Mfs \\
\hline Isolation effect (target island) & 1 & Mit & Mit/Mft \\
\hline Source islandxtarget island & 4 & Mst & Mst/Mfst \\
\hline Fen system $\times$ source island (=source populations) & 8 & Mfs & Mfs/Mfst \\
\hline Fen system $\times$ target island (=target populations) & 8 & Mft & Mft/Mfst \\
\hline Fen system $\times$ source island $\times$ target island & 16 & Mfst & Mfst/Mres \\
\hline Residuals & $n=45$ & Mres & \\
\hline
\end{tabular}

Table 2 Results of ANOVA (GLM procedure) on Carex davalliana fitness traits in a common garden experiment $(n=84)$

\begin{tabular}{|c|c|c|c|c|c|}
\hline \multicolumn{2}{|c|}{ Source of variation } & \multirow[t]{2}{*}{$d f$} & \multirow{2}{*}{$\begin{array}{l}\begin{array}{l}\text { No. tillers } \\
\mathrm{F}\end{array} \\
0.01\end{array}$} & \multirow{2}{*}{$\begin{array}{l}\text { Biomass } \\
\text { F } \\
0.01\end{array}$} & \multirow{2}{*}{$\begin{array}{l}\begin{array}{l}\text { No. flowering tillers } \\
\text { F }\end{array} \\
1.45\end{array}$} \\
\hline Region & & & & & \\
\hline Fen system & & 3 & 1.13 & 1.86 & 0.21 \\
\hline Habitat islands & $\begin{array}{l}\text { Habitat size effect } \\
\text { Isolation effect }\end{array}$ & $\begin{array}{l}1 \\
1\end{array}$ & $\begin{array}{r}11.6^{*} \\
3.61\end{array}$ & $\begin{array}{l}9.84^{*} \\
2.67\end{array}$ & $\begin{array}{c}21.9^{* * *} \\
0.08\end{array}$ \\
\hline Populations & & 6 & 0.68 & 0.55 & 0.09 \\
\hline
\end{tabular}

$* P<0.05, * * P<0.01$

between habitat island types, we used analysis of deviance (Genstat, Payne et al. 1995) with the complementary log-log link (Candy 1986). We calculated ratios of mean deviance changes (quasi $F$-values), which approximately follow the $F$-distribution (Payne et al. 1995). To correct for actual population sizes in the habitat islands, we also performed all analyses with log-transformed population size as a covariable. Population sizes of both species, which were estimated as the number of flowering individuals in 1999 (D. A. P. Hooftman and M. Diemer, submitted), were significantly higher in the main islands than in the small islands (Carex, $F_{1,10}=65, P<0.001 ;$ Succisa, $F_{1,10}=27, P<0.001$ ), and not significantly different between the near and distant small islands (Carex, $F_{1,10}=2.7, P>0.13$; Succisa, $F_{1,10}=0.02, P>0.8$ ). As a consequence, population size was positively correlated with habitat size. Inclusion of the covariable population size may have revealed effects of small habitat size independent of small population size. As mentioned previously, we also performed all analyses with the log-transformed average seed mass as covariable in the model. This covariable was not significantly different between different habitat island types, consequently, inclusion of this covariable never changed the results. The results of analyses incorporating the covariable population size will only be mentioned in instances when they deviate from the original model.

\section{Results}

Common garden experiment

\section{Carex}

Fourteen months after the start of the experiment, plants of Carex had on average a total aboveground biomass of $6.8 \pm 0.4 \mathrm{~g}, 274 \pm 12$ tillers, and $8.2 \pm 1.7$ flowering tillers (43\% of all plants flowered). Plants from small islands produced on average $35 \%$ less biomass, $30 \%$ fewer tillers and $45 \%$ fewer flowering tillers than plants from the main islands (all $P<0.05$, Table 2, Fig. 1). There were no

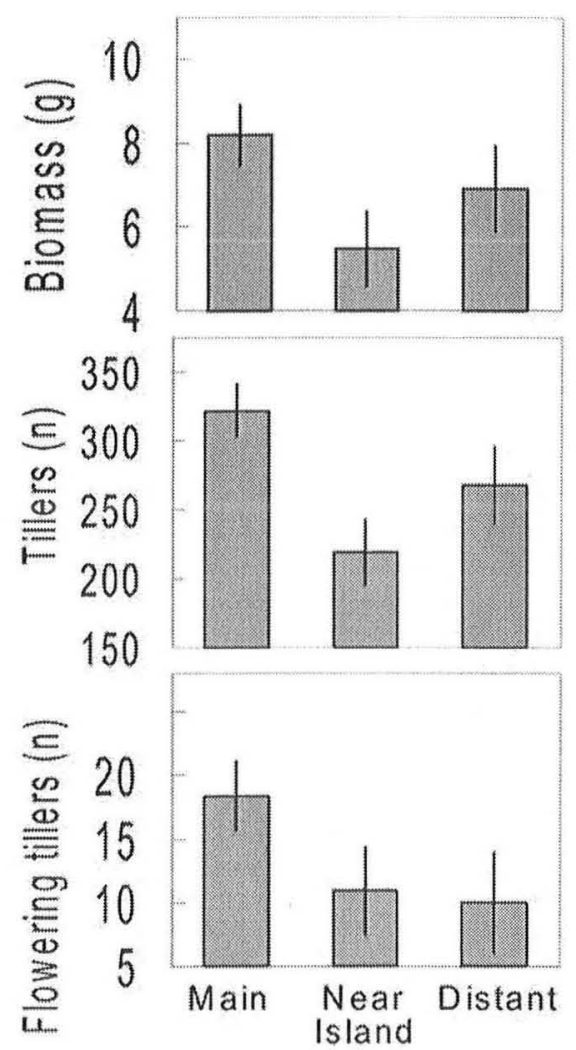

Fig. 1 Effect of the habitat island types of origin on the mean aboveground biomass, the mean number of tillers, and the mean number of flowering tillers produced per plant of Carex davalliana in a common garden experiment. Error bars represent SEMs 
Fig. 2 Effect of the habitat island types of origin on the mean number of rosettes, the mean aboveground biomass, the mean number of flower heads, and the mean number of flowers per flower head produced per plant of Succisa pratensis in a common garden experiment. Error bars represent SEMs
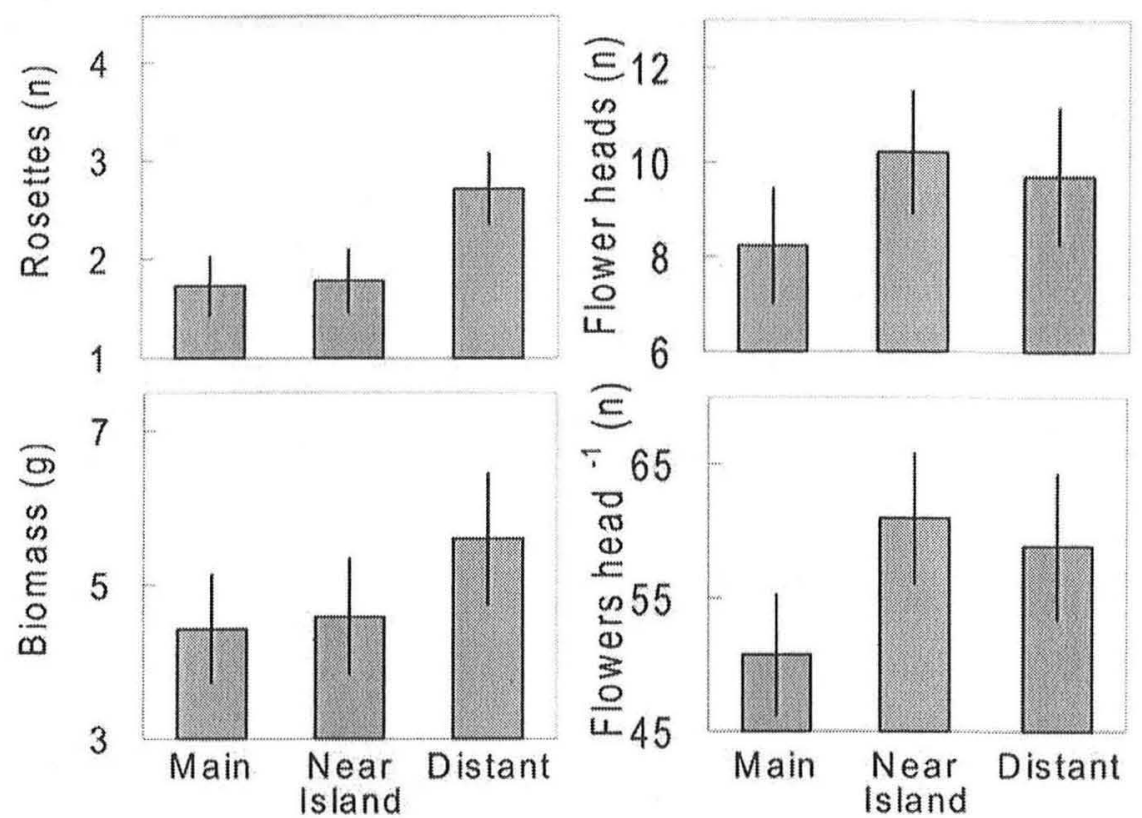

Table 3 Results of ANOVA (GLM procedure) on Succisa pratensis fitness traits in a common garden experiment ( $n=140$ )

\begin{tabular}{|c|c|c|c|c|c|c|}
\hline \multicolumn{2}{|c|}{ Source of variation } & \multirow{2}{*}{$\frac{d f}{1}$} & \multirow{2}{*}{$\begin{array}{l}\begin{array}{l}\text { No. rosettes } \\
\text { F }\end{array} \\
5.33(P=0.08)\end{array}$} & \multirow{2}{*}{$\begin{array}{l}\text { Biomass } \\
\mathrm{F} \\
1.16\end{array}$} & \multirow{2}{*}{$\begin{array}{l}\text { No. flower heads } \\
\text { F } \\
0.52\end{array}$} & \multirow{2}{*}{$\begin{array}{l}\text { No. flowers per flower head } \\
\text { F }\end{array}$} \\
\hline Region & & & & & & \\
\hline Fen system & & 4 & 1.06 & $2.89 *$ & $2.97 *$ & 2.27 \\
\hline Habitat islands & $\begin{array}{l}\text { Habitat size effect } \\
\text { Isolation effect }\end{array}$ & $\begin{array}{l}1 \\
1\end{array}$ & $\begin{array}{l}2.00 \\
7.40 *\end{array}$ & $\begin{array}{l}3.26(P=0.09) \\
0.11\end{array}$ & $\begin{array}{l}5.34^{*} \\
0.50\end{array}$ & $\begin{array}{c}12.5 * * \\
1.13\end{array}$ \\
\hline Populations & & 9 & 0.76 & 0.47 & 0.38 & 0.24 \\
\hline
\end{tabular}

$* P<0.05, * * P<0.01$

significant differences in these traits between the near and distant small islands (Table 2). Because population and habitat size were strongly correlated in Carex, the significance of the habitat size effect disappeared, when we included population size as a covariable in the model.

\section{Succisa}

Fifteen months after the start of the experiment, plants of Succisa had on average a total aboveground biomass of $4.9 \pm 0.4 \mathrm{~g}, 2.0 \pm 0.2$ rosettes, $9.4 \pm 0.7$ flower heads, and $57 \pm 3$ flowers per flower head $(87 \%$ of all plants flowered). Plants from small islands produced on average $19 \%$ more biomass, $10 \%$ more rosettes, $14 \%$ more flower heads, and 35\% more flowers per flower head (Fig. 2) than plants from the main islands. This effect was significant for the number of flowers per flower head $(P<0.01)$, number of flower heads $(P<0.05)$ and marginally significant for the biomass produced per plant $(P=0.09)$. In addition, plants from the distant island produced $32 \%$ more rosettes than plants from the near island $(P<0.05$, Table 3, Fig. 3). When including popu- lation size as a covariable in the model, the effects became stronger for rosettes and biomass $(P<0.01$ and $P<0.05$, respectively), whereas the effects on number of flower heads and flowers per flower head disappeared, indicating that the effect of habitat size and population size were strongly correlated.

\section{Reciprocal transplant experiments}

\section{Seeds of Carex}

Nine months after the start of seed transplant the experiment, on average 2.1 additional seedlings of Carex occurred in inseeding subplots, compared to control subplots, which represents an increase of $21 \%$ $(P<0.001$, Table 4$)$. One year later, 0.5 additional adult tillers remained relative to the control subplots $(+2.1 \%$, $P<0.001$, Table 4). There were no significant differences in germination and establishment rates among the three island types from which seeds originated and in which seeds were sown (Table 4). This suggests that habitat size and isolation did not affect the seed quality or establish- 


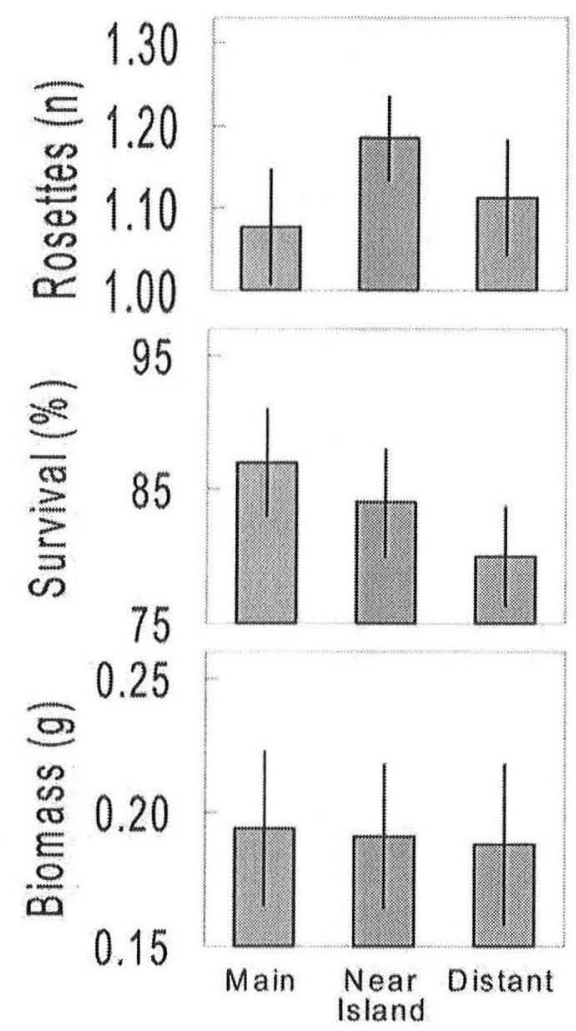

Fig. 3 Effect of the habitat island types of origin on the mean number of rosettes, mean survival rate of genets, and the mean aboveground biomass produced per plant of $S$. pratensis in a reciprocal transplant experiment. Error bars represent SEMs. Results shown are pooled data of "home" and "away" planted plants

Table 4 Results of ANOVA (procedure GLM) on reciprocal transplanting of seeds of $C$. davalliana and $S$. pratensis in 1998 In 1999 , a second series of $S$. pratensis seeds was transplanted. A ment of Carex. However, there was a significant positive correlation between size of the source population and the germination and establishment rate of seedlings $(P<0.05)$.

\section{Seeds of Succisa}

Ten months after the start of the seed transplant experiment, the number of seedlings of Succisa was not significantly higher in the subplots in which we had experimentally sown seeds compared to control subplots. However, 1 year later, on average 0.9 more plants had become established in the sown subplots, compared to the controls $(+263 \%, P<0.01$, Table 4). In the second experiment (which started in 1999), we found on average 0.4 seedlings more in the experimental subplots than in the control subplots $(+39 \%, P<0.001)$. There were no significant differences in germination and establishment rates among the three island types from which seeds originated and in which seeds were experimentally sown (Table 4), which suggests that habitat size and isolation did not affect the seed quality or establishment of Succisa. However, there was a significant positive correlation between the size of the source population and germination in the second experiment $(1999 ; P<0.05)$, and a marginally significant one in the first experiment $(1998 ; P=0.07)$.

\section{Seedling establishment of Succisa}

Fifteen months after the start of the seedling transplant experiment, $84 \%$ of all plants in the field had survived. The surviving plants had produced a mean total above-

\begin{tabular}{|c|c|c|c|c|c|c|c|c|}
\hline \multirow[t]{3}{*}{ Source of variation } & \multicolumn{4}{|c|}{ C. davalliana } & \multicolumn{4}{|c|}{ S. pratensis } \\
\hline & \multicolumn{2}{|c|}{$\begin{array}{l}\text { Germination } \\
\text { in } 1999 \\
(n=165)^{\mathrm{a}}\end{array}$} & \multicolumn{2}{|c|}{$\begin{array}{l}\text { Establishment } \\
\text { in } 2000 \\
(n=171)^{\mathrm{a}}\end{array}$} & \multicolumn{2}{|c|}{$\begin{array}{l}\text { First series } \\
\text { Establishment in } \\
2000(n=174)^{\mathrm{a}}\end{array}$} & \multicolumn{2}{|c|}{$\begin{array}{l}\text { Second series, } \\
\text { Germination in } 2000 \\
(n=171)^{\mathrm{a}}\end{array}$} \\
\hline & $d f$ & $\mathrm{~F}$ & $d f$ & $\mathrm{~F}$ & $d f$ & $\mathrm{~F}$ & $d f$ & \\
\hline \multicolumn{9}{|c|}{ Comparison of plots with seeds added relative to controls } \\
\hline $\begin{array}{l}\text { Inseeding effect } \\
\text { Residuals }\end{array}$ & $\begin{array}{l}109 \\
110\end{array}$ & $1.91^{* * * * *}$ & $\begin{array}{l}113 \\
114\end{array}$ & $3.43 * * *$ & $\begin{array}{l}115 \\
116\end{array}$ & $1.68 * * *$ & $\begin{array}{l}113 \\
114\end{array}$ & $3.15 * * *$ \\
\hline \multicolumn{9}{|l|}{ Effects of habitat fragmentation } \\
\hline Region & 1 & $\begin{array}{l}6.93 \\
(P=0.08)\end{array}$ & 1 & 1.75 & 1 & 1.52 & 1 & 0.64 \\
\hline $\begin{array}{l}\text { Fen system } \\
\text { Habitat islands }\end{array}$ & 3 & $3.06^{*}$ & 3 & $10.0^{* * * * *}$ & 3 & $5.29 * *$ & 3 & $12.3 * * *$ \\
\hline Habitat size effect (source island) & 1 & 2.20 & 1 & 0.25 & 1 & 0.00 & 1 & 1.43 \\
\hline Habitat size effect (target island) & 1 & 0.02 & 1 & 1.50 & 1 & 3.69 & 1 & 0.08 \\
\hline Isolation effect (source island) & 1 & 1.84 & 1 & 0.01 & 1 & 0.04 & 1 & 0.00 \\
\hline Isolation effect (target island) & 1 & 0.87 & 1 & 2.78 & 1 & 0.00 & 1 & 0.24 \\
\hline Source islandxtarget island & 4 & 0.83 & 4 & 1.19 & 4 & 2.17 & 4 & 0.87 \\
\hline Populations (source) & 8 & 3.10 & 8 & 2.25 & 8 & 1.41 & 8 & 1.15 \\
\hline Populations (target) & 8 & $23.7 * * *$ & 8 & $10.6 * * *$ & 8 & 1.78 & 8 & 2.40 \\
\hline
\end{tabular}

$* P<0.05, * * P<0.01, * * * P<0.001$

a Without control plots

comparison of plots with seeds added relative to controls (inseeding effect, calculated per plot) and effects of habitat fragmentation are shown 
Table 5 Results of ANOVA (GLM procedure) on S. pratensis fitness traits in a reciprocal transplant experiment

\begin{tabular}{lllll}
\hline Source of variation & $d f$ & $\begin{array}{l}\text { Survival } \\
(n=303)\end{array}$ & $\begin{array}{l}\text { No. rosettes } \\
(n=245) \\
\mathrm{F}\end{array}$ & $\begin{array}{l}\text { Biomass } \\
(n=245)\end{array}$ \\
\hline Region & 1 & 3.20 & 0.95 & 0.75 \\
Fen system & 3 & 0.17 & 0.86 & 2.54 \\
Habitat islands & 1 & 0.23 & $16.4^{* * *}$ & 2.77 \\
Habitat size effect (source island) & 1 & 0.97 & 2.34 & 1.10 \\
Habitat size effect (target island) & 1 & 0.21 & $3.84(P=0.08)$ & 0.24 \\
Isolation effect (source island) & 1 & 0.43 & 1.73 & 0.45 \\
Isolation effect (target island) & 4 & 0.79 & 1.37 & 0.28 \\
Source island×target island & 8 & 1.47 & 0.27 & 1.55 \\
Populations (source) & 8 & 2.09 & 1.53 & 1.35 \\
Populations (target) & & & &
\end{tabular}

$* P<0.05, * * P<0.01$ ground biomass of $0.19 \pm 0.02 \mathrm{~g}$ and $1.14 \pm 0.03$ rosettes. After 15 months $2.6 \%$ of all plants had flowered. Survival of seedlings and biomass production of the survivors did not differ significantly between the different island types (Fig. 3, Table 5). Plants of Succisa originating from small islands produced on average $7 \%$ more rosettes than plants originating from main islands $(P<0.01$, Table 5, Fig. 3$)$. However, plants originating from distant islands produced $6 \%$ fewer rosettes than plants originating from near islands $(P=0.08$, Table 5). The effect of habitat size was not significant anymore, when we included population size as a covariable in the model, indicating that the effects of habitat size and population size were strongly correlated. Similarly, the marginal, significant effect of isolation disappeared when we included population size as a covariable in the model.

\section{Discussion}

In the reciprocal transplant experiment with seeds of Carex and seeds and seedlings of Succisa, there were no significant effects of the size and degree of isolation of the local habitat islands on germination, survival and growth of plants (Tables 4, 5). Under the common environmental conditions in the garden and field, however differences in growth and reproduction between plants originating from large (main), adjacent small (near) and remote small (distant) habitat islands were evident in both species. These results suggest that differences between plants of different habitat islands are genetic and cannot be explained by systematic differences in environmental conditions among main, near and distant islands. A conclusion supported by unpublished data on community biomass and leaf area index (see below). Despite this lack of systematic differences among island types, local conditions of individual habitat islands certainly differ to a small extent, e.g. in Carex (Table 4). Another possible explanation for the observed effects could be attributed to maternal environmental carry-over effects via the seeds (Schmitt et al. 1992; Schmid and Dolt 1994). However, this explanation is unlikely since mean seed mass did not differ between the three habitat island types and the results never changed when we included seed mass as a covariable in the analyses. Furthermore, there were no statistical differences among habitat island types for two types of environmental conditions: aboveground biomass production (D. A. P. Hooftman and M. Diemer, submitted) and canopy structure (van den Bogert, unpublished data).

Genotypic differences between plants from different habitat islands

\section{Carex}

In the reciprocal seed transplant experiment, we did not find higher germination and establishment rates for "home" than for "away" seeds of Carex, nor did we find significant differences between island types where seeds were sown. However, the germination rate was positively correlated with the size of the population of origin (Table 4), suggesting a genotypic effect of population size on seed quality, as observed by Helenurm (1998), and Fischer and Matthies (1998). Indirect evidence from another field study (D. A. P. Hooftman and M. Diemer, submitted), using the same habitat islands, supports this contention, i.e. the proportion of seedlings of all plants of Carex decreased by $39 \%$ in isolated islands compared to main islands

In the garden, plants of Carex originating from small island types produced less aboveground biomass, fewer tillers, and fewer flowering tillers than plants from the main island (Table 2). In small habitats, it is likely that genetic drift in the small populations has resulted in lowered genetic variation, more inbreeding and consequently reductions in fitness through inbreeding depression (Barrett and Kohn 1991; Ellstrand and Elam 1993). This effect has been observed for many rare plant species (Menges 1990; Ouborg et al. 1991; Oostermeijer et al. 1995; Heschel and Paige 1995; Fischer and Matthies 1998; Fischer et al. 2000), but to our knowledge, this is among the first reports of such an effect in a common species. As a further consequence of reduced genetic variation in small habitat islands, bi-parental inbreeding may have increased in this dioecious species (Ellstrand 
and Elam 1993; Fischer et al. 2000; Richards 2000) further lowering the genetic variability.

\section{Succisa}

In the reciprocal seed transplant experiment, we also detected no statistically significant effects of habitat fragmentation on seed quality in Succisa. However, since seed germination was very low, our sample sizes may have masked significant differences.

Nevertheless, the germination and establishment rates of Succisa in the field were positively correlated with the size of the population of origin, suggesting a genotypic effect of population size on seed quality, similar to the one observed for Carex. Also for Succisa, indirect evidence from a field study (D. A. P. Hooftman and M. Diemer, submitted), using the same habitat islands supports this contention, i.e. the proportion of seedlings of all sampled plants of Succisa decreased by $80 \%$ in small islands compared to main islands.

In the garden, plants originating from small habitat islands produced more biomass, rosettes, flower heads, and flowers per flower head (Table 3 ). In the reciprocal seedling transplant experiment, we also found that plants from small and isolated islands produced more rosettes (Table 5). Theory and available data predict that genetic drift and a higher inbreeding level should most likely result in a lower fitness of plants as a consequence of inbreeding depression in small habitat islands (Ellstrand and Elam 1993; Young et al. 1996; Fischer and Matthies 1998; Lienert et al. 2002b), as observed in Carex. The higher fitness of plants of Succisa from small habitat islands relative to main islands, therefore, suggest that genetic differences between plants from different island types are more likely to be caused by differential selection pressures between island types, than by genetic drift. The higher investment in sexual reproductive structures and vegetative growth observed in plants from small islands suggests that there has been selection for both sexual and clonal reproductive traits. Because the reciprocal transplant experiment showed that "home" plants did not perform better than "away" plants, we believe that biotic interactions are more likely a explanation for this selection, rather than adaptations to local abiotic factors. The number and diversity of pollinating insects may decrease in small habitat islands (Wettstein and Schmid 1999), which in insect-pollinated species such as Succisa, may result in pollen limitation, and consequently reduced reproduction (Agren 1996; Kwak et al. 1998). Therefore, plants, which produce more flowers and thereby attract more pollinators, or plants with a higher investment in clonal reproduction may be selected for. This mechanism is less likely in wind-pollinated species, such as Carex. In a previous study (D. A. P. Hooftman and M. Diemer, submitted), we found a decrease in the proportion of seedlings in small habitat islands, which indicates that the observed increase in the number of flowers in plants from small habitat islands does not result in a higher germi- nation rate and a higher rate of seedling establishment in the field.

\section{Conclusions}

Our results show that differences in germination rate, growth, and flowering traits for both Carex and Succisa between large, and small near and isolated habitat islands are most likely genotypic. Local environmental conditions and maternal carry-over effects cannot explain the observed differences in plant fitness among habitat island types.

The contrast of the near versus the distant island (=isolation effect) in our experimental design allowed us to detect the effects of potential gene flow, which could counteract the effects of small habitat size. However, we were unable to document unambiguous evidence of such gene flow to near islands for either species. Virtually all observed changes in plant fitness components were attributable to the effects of small habitat size, which are likely to act through concomitant differences in population size. Therefore we conclude that gene flow to near habitat islands, located roughly $50 \mathrm{~m}$ from the main island, is very low for these species and insufficient to counteract the effects of small habitat size for these species.

Moreover, this study is to our knowledge, among the first studies to show evidence for genetic effects of habitat fragmentation on components of individual fitness in common fen meadow species. Obviously, the fitness components examined in our study cannot reflect lifetime fitness. Although lifetime fitness of perennial plants, and especially of plants with clonal growth, is notoriously difficult to measure (Winkler and Fischer 1999), we measured both vegetative and reproductive traits; the further inclusion of fitness attributes should therefore not affect our conclusions. Furthermore, we found effects of habitat fragmentation on population structure in both species, which are in line with the results of this study (D. A. P. Hooftman and M. Diemer, submitted). The results of a closely related study, using allozyme electrophoreses, essentially supports the conclusion derived here (D. A. P. Hooftman et al., submitted). In Carex, we found a decrease in the number of alleles per locus, and heterozygosity in populations of small and isolated habitat islands, which may indicate genetic drift. In Succisa, we found a marginal significant differentiation $\left(F_{\text {st }}\right)$ between populations in small habitat islands and main islands, which may be indicative of the selection for specific genotypes suggested in this study. Likewise in a formerly common fen meadow species, Swertia perennis, plant fitness and isozyme variability were significantly reduced in small isolated habitat islands (Lienert et al. 2002b, 2002c). Furthermore, negative correlations between fitness components and genetic variability were observed elsewhere (Oostermeijer et al. 1995; Fischer and Matthies 1998; Fischer et al. 2000), although this relationship may 
not be universal (Ouborg and van Treuren 1995; Lammi et al. 1999).

Our hypothesis that habitat fragmentation affects not only rare species, but common habitat-specific species as well, was substantiated, even though populations of common habitat-specific species in small habitat islands are much larger than populations of rare species, facing similar fragmentation. Moreover, our study shows that the effects of habitat fragmentation are not uniform among species, but may depend on their life history. Since only two habitat-specific species are used, in conjunction with Swertia data (Lienert et al 2002b, 2002c), generalization to include other species and habitat types is still difficult. It is unclear if the magnitude of the effects observed here indeed may threaten isolated or small populations in the long-term or if compensatory demographic effects may stabilize these populations. Since common species comprise the matrix of the community, a change in population viability of those species may affect the community as a whole. Ongoing habitat fragmentation supports the need for additional research into common species in other habitats and the development of long-term monitoring programs.

Acknowledgements We would like to thank Regula Billeter, Bernhard Schmid, Dani Prati, and three anonymous reviewers for valuable comments on earlier versions of this manuscript. We are grateful to Hilda van 't Riet, Angelika von Foerster, and Jeroen van den Bogert for help in the garden and field. Further, we would like to thank all cantonal and municipal authorities, owners, and tenants for the permission to work on their sites. This study was supported by NF-grant 31-50669.97 to M. D.

\section{References}

Adams AW (1955) Succisa pratensis. J Ecol 43:709-718

Agren J (1996) Population size, pollinator limitation, and seed set in the self-incompatible herb Lythrum salicaria. Ecology 77:1779-1790

Antonovics J, Primack RB (1982) Experimental ecological genetics in Plantago. VI. The demography of seedling transplants of $P$. lanceolata. J Ecol 70:55-75

Barrett SCH, Kohn JR (1991) Genetic and evolutionary consequences of small population size in plants: implications for conservation. In: Falk DA, Holsinger KE (eds) Genetics and conservation in plants. Oxford University Press, New York, pp 3-30

Berge G, Nordal I, Hestmark G (1998) The effect of breeding systems and pollination vectors on the genetic variation of small plant populations within an agricultural landscape. Oikos 81:17-29

Binz A, Heitz C (1990) Schul- und Exkursions Flora für die Schweiz. Schwabe, Basel

Boyce MS (1992) Population viability analysis. Annu Rev Ecol Syst 23:481-506

Candy SG (1986) Fitting a parametric log-linear hazard function to grouped survival data. GLIM Newslett 13:28-31

Ellenberg H (1996) Vegetation Mitteleuropas mit den Alpen in ökologischer, dynamischer und historischer Sicht. Ulmer, Stuttgart

Ellstrand NC, Elam DC (1993) Population genetic consequences of small population size: implications for plant conservation. Annu Rev Ecol Syst 24:217-242
Eriksson O (1996) Regional dynamics of plants: a review of evidence for remnant, source-sink and metapopulations. Oikos 77:248-258

Fischer M, Matthies D (1998) Effects of population size on performance in the rare plant Gentianella germanica. J Ecol 86:195-204

Fischer M, Stöcklin J (1997) Local extinctions of plants in remnants of extensively used calcareous grasslands 19501985. Conserv Biol 11:727-737

Fischer M, van Kleunen M, Schmid B (2000) Genetic allele effects on performance, plasticity, and developmental stability in a clonal plant. Ecol Lett 3:530-539

Galloway LF, Fenster CB (2000) Population differentiation in an annual legume: local adaptation. Evolution 54:1173-1181

Görs S (1977) Ordnung Tofieldietalia. In: Oberdorfer E (ed) Süddeutsche Pflanzengeselschaften. Fischer, Stuttgart, pp 243274

Harrison S, Hastings A (1996) Genetic and evolutionary consequences of metapopulation structure. Trends Ecol Evol 11:180183

Heglund SJ, van Leeuwen M, Oostermeijer JGB (2001) Population structure of Salvia pratensis in relation to vegetation and management of Dutch dry floodplain grasslands. J Appl Ecol 38:1277-1289

Helenurm K (1998) Outplanting and differential source population success in Lupinus guadalupensis. Conserv Biol 12:118-127

Heschel MS, Paige KN (1995) Inbreeding depression, environmental stress, and population size variation in scarlet gillia (Ipomopsis aggregata). Conserv Biol 9:126-133

Hooftman DAP, Diemer M, Lienert J, Schmid B (1999) Does habitat fragmentation reduce the long-term survival of isolated populations of dominant plants? A field design. Bull Geobot Inst ETH 65:59-72

Kwak MM, Velterop O, van Andel J (1998) Pollen and gene flow in fragmented habitats. Appl Veg Sci 1:37-54

Lammi A, Sikamaki P, Mustajarvi K (1999) Genetic diversity, population size, and fitness in central and peripheral populations of a rare plant Lychnis viscaria. Conserv Biol 13:10691078

Landolt E (1991) Gefähdrung der Farn- und Blütenpflanzen in der Schweiz mit gesamtschweizerischen und regionalen roten Listen. EDMZ, Bern

Lauber K, Wagner C (1998) Flora Helvetica. Haupt, Bern

Levin DA (1988) Consequences of stochastic elements in plant migration. Am Nat 132:643-651

Lienert J, Fischer M, Diemer M (2002a) Local extinctions of the wetland specialist Swertia perennis L. (Gentianaceae): a revisitation study based on herbarium records. Biol Conserv 103:65-76

Lienert J, Diemer M, Schmid B (2002b) Effects of isolation distance and habitat area on population structure and fitness of a common fen species, Swertia perennis L. (Gentianaceae). Basic Appl Ecol 3:101-114

Lienert J, Fischer M, Schneller J, Diemer M (2002c) Isozyme variation of the wetland specialist Swertia perennis L. (Gentianaceae) in relation to habitat size and isolation, and to plant fitness. Am J Bot 89:801-811

Menges ES (1990) Population viability for an endangered plant. Conserv Biol 4:52-62

Morris WF (1993) Predicting consequences of plant spacing and biased movement for pollen dispersal by honey bees. Ecology 74:493-500

Nagy ES, Rice KJ (1997) Local adaptation in two subspecies of an annual plant: implications for migration and gene flow. Evolution 51:1079-1089

Oostermeijer JGB, van 't Veer R, den Nijs JCM (1994) Population structure of the rare, long lived perennial Gentiana pneumonanthe in relation to vegetation and management in The Netherlands. J Appl Ecol 31:428-438

Oostermeijer JGB, van Eijck MW, van Leeuwen NC, den Nijs JCM (1995) Analysis of the relationship between allozyme hetero- 
zygosity and fitness in the rare Gentiana pneumonanthe. J Evol Biol 8:739-759

Ouborg NJ (1993) Isolation, population size and extinction: the classical and metapopulation approaches applied to vascular plants along the Dutch Rhine-system. Oikos 66:298-308

Ouborg NJ, van Treuren R (1995) Variation in fitness-related characters among small and large populations of Salvia pratensis. J Ecol 83:369-380

Ouborg J, van Treuren R, van Damme JMM (1991) Morphological variation and fitness components in populations of varying size of Salvia pratensis L. and Scabiosa columbaria L. Oecologia 86:359-367

Payne RW, Lane PW, Digby PGN, Harding SA, Leech PK, Morgan GW, Todd AD, Thompson G, Tunnicliffe Wilson G, Welham SJ, White PR (1995) GENSTAT 5. Lawes Agricultural Trust, Harpenden

Peintinger M (1999) The effects of habitat area, management, and altitude on species diversity in montane wetlands. $\mathrm{PhD}$ dissertation. University of Zürich, Zürich

Power ME, Tilman D, Estes JA, Menge BA, Bond WJ, Mills LS, Daily G, Castilla JC, Lubchenco J, Paine RT (1996) Challenges in the quest for keystones. Bioscience 46:609-620

Primack RB, Miao SL (1992) Dispersal can limit local plant distribution. Conserv Biol 6:513-519

Richards CM (2000) Inbreeding depression and genetic rescue in a plant metapopulation. Am Nat 155:383-394

Saunders DA, Hobbs RJ, Margules CR (1991) Biological consequences of ecosystem fragmentation: a review. Conserv Biol 5:18-32

Schemske DW, Husband BC, Ruckelshaus MH, Goodwillie C, Parker IM, Bishop JG (1994) Evaluating approaches to the conservation of rare and endangered species. Ecology 75:584606
Schmid B (1985) Clonal growth in grassland perennials. III. Genetic variation and plasticity between and within populations of Bellis perennis and Prunella vulgaris. J Ecol 73:819-830

Schmid B (1992) Phenotypic variation in plants. Evol Trends Plants 6:45-60

Schmid B, Dolt C (1994) Effects of maternal and paternal environment and genotype on offspring phenotype in Solidago altissima $\mathrm{L}$. Evolution 48:1525-1549

Schmitt J, Niles J, Wulff RD (1992) Norms of reactions of seed traits to maternal environments in Plantago lanceolata. Am Nat 139:451-466

Stöcklin J, Fischer M (1999) Plant with longer-lived seeds have lower extinction rates in grassland remnants 1950-1985. Oecologia 120:539-543

Van Tienderen PH, van der Toorn J (1991) Genetic differentiation between populations of Plantago lanceolata. I. Local adaptation in three contrasting habitats. J Ecol 79:27-42

Van Treuren R, Bijlsma R, van Delden W, Ouborg NJ (1991) The significance of genetic erosion in the process of extinction. I. Genetic differentiation in Salvia pratensis and Scabiosa columbaria in relation to population size. Heredity 66:181-189

Westoby M, Leishman M, Lord J (1996) Comparative ecology of seed size and dispersal. Phil Trans $\mathrm{R} \mathrm{Br}$ Soc Lond 351:13091318

Wettstein W, Schmid B (1999) Conservation of anthropod diversity in montane wetlands: effects of altitude, habitat quality and habitat fragmentation on butterflies and grasshoppers. J Appl Ecol 36:363-373

Winkler E, Fischer M (1999) Modelling the competitiveness of clonal plants by complementary analytical and simulation approaches. Oikos 85:217-233

Young AG, Boyle T, Brown T (1996) The population genetic consequences of habitat fragmentation for plants. Trends Ecol Evol 11:413-418 